\title{
Global interactive media design industry's sectoral analysis on interactive media awards
}

\begin{abstract}
Interactive Media Design Industry continues to manipulate and rearrange the dynamics of entertainment, education, production and consumption and some similar topics in the general media. As an important new formation, "Interactive Media Awards" continues to give awards and helps us to make observations about the trends of the industry since 2006. This formation surveys all kinds of projects that have been made by Interactive media companies all over the world. It gives awards in two different sections and it is quite sufficient to analyze the general trends of the industry. These awards are very well recognized internationally. That is why it is possible that the research about that work line might find an important place in international academic circles. All over the world, the award winning from 2006 in the sector of Interactive Media had many contributions to the World. After analyzing all the data from award winnings in the chosen areas basically shows that Turkey has a very important part in the field. In a lot of different areas Turkey made very important accomplishments when it comes to Interactive Media. Both Design aspects and advertisement part of the field was used very efficiently. Turkey shows its improvement in the area with shown statistics and its development trend goes higher according to time. The findings of this research will possibly guide the future projects and might also add value to the education model of universities.
\end{abstract}

\author{
Lutfu Kaplanoglu ${ }^{1}$ \\ Ilkan Devrim Dinc ${ }^{2}$ (D) \\ ${ }^{1}$ Yıldız Technical University, \\ Department of Combined Arts \\ istanbul, Turkey \\ ${ }^{2}$ Maltepe University, Department \\ of Animation, Istanbul, Turkey \\ Corresponding author: \\ Ilkan Devrim Dinc \\ e-mail:devrimdinc@maltepe.edu.tr
}

First recieved: 08.06.2019. Accepted: 08.10.2019.

\section{KEY WORDS}

Interactive, media, design, web, internet, advertisement, global, award

\section{Introduction}

It may be assumed that the requirements of science fiction universe initiated at the beginning of second millennium and affecting mankind for the last century has started to reveal themselves. It is clear that numerous movies and literary works that were made at the beginning of year 2000 have raised the expectations of people from media and technology. With the assumption of mankind having struggle to be satisfied by the mere consumption of single media/mean, whose satisfaction threshold has been increased significantly; a new era has begun in which media agencies have realized an interactive production principle as a new orientation. "Interactive media is the integration of digital media including combinations of electronic text, graphics, moving images, and sound, into a structured digital computerized environment that allows people to interact with the data for appropriate purposes. The digital environment can include the Internet, telecoms and interactive digital television" (England \& Finney, 2002).

This article covers the interactive media design idea suggested with the principle of demonstrating the product in interaction with a target group. The subject will be extended in scope of projects based on the interactive promotion of entire company or part of the company to be advertised. Such a new approach that will allow media to interact with the target to be reached has been attempted with minimal initiatives 
both in literary and cinematographic works since 1950s; however, as of the beginning of 2000s, such media form has become widespread by providing technological opportunities to allow easy access to target groups by flash memories and websites. Now, companies willing to introduce themselves achieve efficiency that will allow interaction with their target groups by using the opportunities of Interactive Media. Interactive Media Awards (Interactive Media Awards, 2017a) as a system that will control the progress of tendencies determined has been continuing its awarding initiatives since 2006 .

Effect and benefits of interactive media design on the production dynamics of countries in global aspect will be queried as a result of this research and an attempt will be made to reveal the progress of sector as an original direction in itself. Organization distributing awards to various interactive media companies in numerous countries in the world in more than hundred sectors contains a very convenient sector to display the general tendencies of the sector. In the awards list on their website, it may be easily seen which interactive media company of which country in which year has won the award for which company. Besides, the direction and development of the sector within years is specified through listing system in which companies have developed projects for whom and in which time. This study, which is drafted by considering all these matters, is significant to orient the sector for the contributions planned to be made from Turkey.

\section{Method}

Since it will be difficult to analyze the tendencies of a sector without using statistical data analysis, we have applied data analysis as a method in this study. Graphs in total by such data will demonstrate the progress in both on international scale and in Turkey and such data will be used in future research.

\section{Population and Sample}

Population of the research is comprised of lists contained in the website of "Interactive Media Awards" award module. In addition to the information provided by the module listing the interactive media company winning the award and the main company, for which the interactive media company has worked, statistical data accessed in relation with such information was used for the purpose of extending this population. Although the information covers the companies that are deemed worthy of the reward in two different branches, awards were approached with equal value to develop a wider perspective and the success of countries were also queried to strengthen the research. The scope of the research was reduced to last three years to shed light on current status to be formed for ten sectors considered more important. To establish the limits of population, it may be considered that we have not encountered any other organization that may serve for the purpose of this research with respect to their interface and award approach compared to interactive media rewards, even though there are numerous awarding platforms on international scale and in Turkey on the internet.

\section{Literature Summary}

Interactive media field contains affinities and similarities with numerous fields such as hypermedia, multimedia, new media and human computer interaction. It is assumed that these fields have been interacting with each other during their emergence and general existence and that it is necessary to recognize them in scope of the general scale of research. It is also necessary to know the link of interactivity with media in literature and the foundation of interactive media. "There are many terms used to denote the interactive nature of digital applications-multimedia, new media and interactive design are common examples. Because the interactive sector has quickly evolved through phases, the terms have often been coined to reflect a phase that then gets surpassed" (England \& Finney, 2002). This is the reason why they have close meanings and there will be specific distinctions that will provide separation in the following period. This arises the requirement to approach all media forms as multi-action.

"The word Multimedia used to have a specialist
connotation for the audio-visual industry. Uses
of multiple or mixed media in such analogue sys-
tems as slide shows or overhead projectors were
known as 'multimedia'. But this specialist use was
superseded by the arrival of digital technology.
Integrated digital media was termed interactive
multimedia and usually shortened to plain multi-
media for convenience." (England \& Finney, 2002)

When it comes to multimedia, level of interaction increases, and information is transmitted to interacted person easily. "Learning with multimedia is a method allowing transmission of message to target by simultaneously addressing more than one sense. Whereas, multimedia concept is defined as simultaneous addressing to more than one sense" (Bulduk, 2015). Such approach will be observed on the web design-based projects suggested in scope of this research. Since web designs are approached basically, human computer interaction is suggested primarily. Basics of interactivity will be linked to exposure of people to artificial interaction created by the codes in computer in scope of this research.

"The term human-computer interaction has only been in widespread use since the early 1980s, but has its roots in more established disciplines. Systematic study of human performance began in earnest at the beginning of the last century 
(twentieth) in factories, with an emphasis on manual tasks."(Dix, Finlay, Abowd \& Beale, 2004)

This and many similar abilities will concretize the limits of human-computer interaction and media design with simultaneous interaction. Besides, media as a determinant in the interaction has technological extension as well as psychological effect because;

"Interaction design is not just about the artifact that is produced, whether a physical device or a computer program, but about understanding and choosing how that is going to affect the way people work. Furthermore, the artifacts we give to people are not just these devices and programs, but also manuals, tutorials, online help systems. In some cases we may realize that no additional system is required at all, we may simply suggest a different way of using existing tools." (Dix, Finlay, Abowd \& Beale, 2004)

Numerous different approaches emerged with the opportunities created by human-computer interaction and a media structure was developed on the basis of interaction on many subjects from advertisement to web design, computer games to phone applications.

Media developing in this direction continues to be developed and formed over "New Media, Hypermedia and Interactive Media." "New media integrate the qualities of interactivity and multimedia within the digital interfaces. The hypermedia interface is changing the human communication system due to its interactive ability as well as the multisensory qualities of the hypermedia" (Mora-Fernández, 2012). Interaction of people with each other causes media and technology to be affected in each other; therefore, interaction will continue to progress on all aspects.

"(...) when the motivated actor decides to activate the multidirectional system of communication, using his interactions over the hypermedia interface, and coding his own representations to communicate them to a new receptor, a.k.a. reader-author, student-professor, author- reader, or the first sender. The most characteristic moment is when the exchange of roles between actors occurs: the sender becomes the receptor and vice versa." (Mora-Fernández, 2012)

Therefore, multi-directional effect of hypermedia on roles and concepts allows interaction to become widespread on the entire media and concretizes the effect made on communication in all directions.

Media is derived from the application forms within the interaction model of new media concept despite having different names. In order to perceive the effect emerged during integration of new media into communication, it will be required to concretize the types of this media more clearly.

"The term 'New media' carries it's own problems as the media associated with the original term are replaced with newer instances of the 'new'. Obsolescence is endemic in the interactive arena. However, the term remains in use although Digital Media and Interactive Media are more sgraph terms and are being used increasingly. The term Interactive Media highlights the interactive connotation that is a key characteristic of the difference between the older style media and the new." (England \& Finney, 2002)

Interactive media becomes more prominent as a significant branch of new media with this aspect and concretizes the limits. Literature is summarized and statistical infrastructure of this research is prepared by addressing this aspect of interactive media since the interaction is the simplest form and basics of the researched are covered by a web interface.

"When the Web quickly became the largest hardware platform, and development for it became the most common form of interactive development, the emphasis on 'media' was dropped in a similar way. This may have been because the capacity for using media other than text on the Web was limited at that time. Skill sets such as Web Design, and Web Development came to the fore and these more specific terms overshadowed the more general terms like Digital Media and Interactive Media." (England \& Finney, 2002)

Therefore, the subject is narrowed down by placing the website in the center in interactive media awards and research is rendered as statistics with the information distinguished within "Interactive Media Design" website and attempted to be analyzed by generating graphs from these statistics.

\section{Data Collection Method}

Only mean used in the research is the interactive media awards, award module. Information provided by this module is combined by using three different methods. The first one is the method of accessing to statistical data to generate graphics that compare the change of awards in years. Attempts are made to compare the companies awarded for three years in order to generate such data. The second one is the method of generating the statistical data to observe the reflections of awards in different sectors. General tendency is demonstrated by composing such data as graphics under different graphs. Third and the last one is the method to present statistical graphs formed according to award winning rates of countries and progress of the sector is attempted to be observed. By using the award search engine in the award module 
of Interactive Media Awards; companies awarded on all sectors are assumed as more important than other sectors sorted for the years 2015, 2016 and 2017 and it is listed which companies have won 317 awards achieved from the graph formed and company profiles provided that accessing to websites of these companies. After listing the countries of companies by determined from their websites, it is accessed through these profiles which country has received how many awards in which year and sector. Graphs are generated by using the percentage rates among the data and data of the research visualized with this method is analyzed. Respectively more than one hundred sectors are listed in the award module of interactive media awards. Since it will be very difficult to sort all sectors available in these lists, award winning profiles of ten sectors comprised mainly of Finance, Tourism, Education, Health and Food of which roles are considered as more important than others on global economy are scanned. This award for company winning the award every year and the digital plaque representing the awarded media company and website establishing connection between plaque and company are listed on the Interactive Media Awards website.

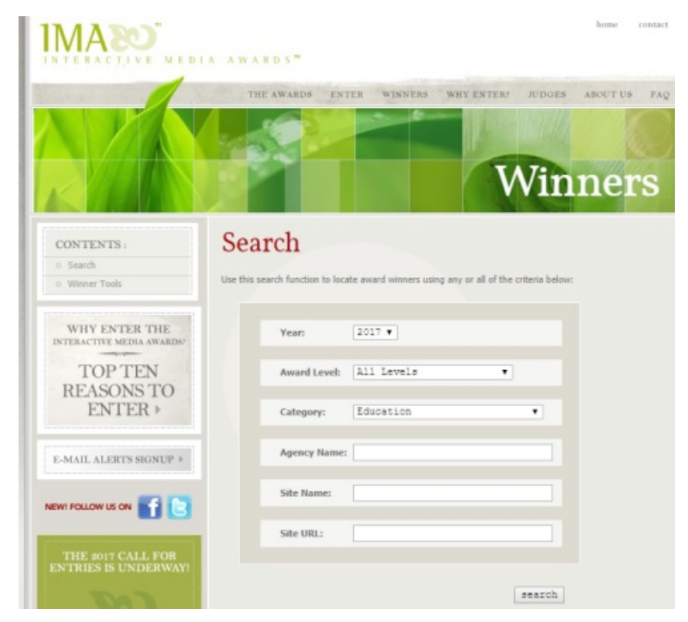

» Figure 1: "IMA" (Interactive Media Awards), award search module

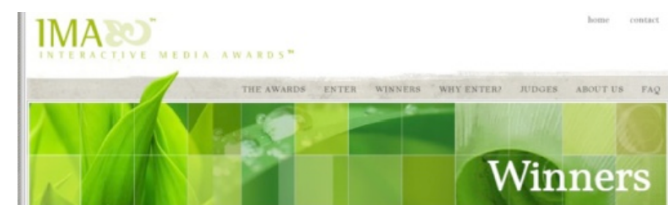

Winners Gallery // 2017

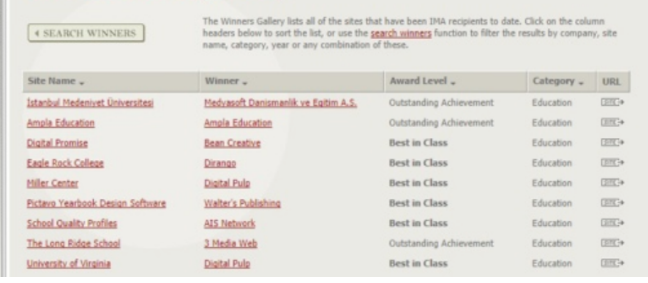

» Figure 2: "IMA" (Interactive Media Awards), list of awards received in education sector in 2017
Year and sector field may be selected through search engine viewed on Figure 1. Number of awards won on the sector determined in that year is listed in sequence. There are two fields in section addressed as "award level" in Figure 1 and even these fields are segregated as "Outstanding Achievement" and "Best in Class", awards are researched in behavior appreciating equal value by ignoring this approach as mentioned previously.

Companies located at top rank on the list of Figure 2 are the companies for which projects are generated. There are interactive companies winning the award under "Winners" category and then award levels and categories are viewed. Then, the item containing web bridge specified as "site" on last rank addresses the website representing the project which is worked for the awarded company.

\section{Analysis of Data}

317 awards distributed in scope of this research for three years are listed provided to achieve websites as mentioned above and they are qualified as national or international on the basis whether their headquarters are gathered in single country or larger part of work load undertaken is gathered in single country or not. Awards in national nature are defined as owned by the awarded country; awards won on international scale have been converted into a category and awards are segregated on country basis.

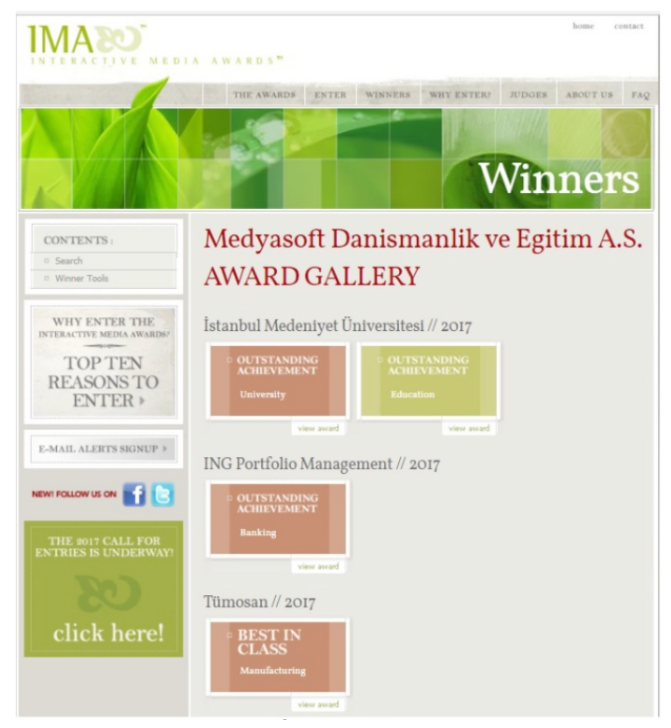

» Figure 3: "IMA" (Interactive Media Awards), plaque list of Medyasoft generating Project for Istanbul Medeniyet University among the awards distributed in education sector in 2017

Sectoral categories are accessed through search module viewed on Figure 1 of website of interactive media awards, information relating to countries is accessed through artificial award plaques in Figure 3 obtained 
from this module. 317 awards having countries and sectoral specifications determined are segregated on year, sector and country basis and the numbers are listed via deductive method. Numeric values deducting the entirety into specific are calculated on special categories specified in findings section and divided into percentages by the authors of this article. After determining these percentages in a level to be reduced into 35 different graphs, some of them are tabulated by the authors of this article in graphic programs and results obtained by these graphs are analyzed.

\section{Findings}

The following (Figure 4) ten sectors are elected with the assumption that they will orient the research with their strength on global market. It is seen that these ten sectors demonstrating existence densely on national and international market have won 317 awards in total from the projects generated by benefitting from the interactive media profession in last three years. Distribution of total number of awards is presented on the following graph on sector basis. Higher ranks are occupied by tourism and education sectors and they are followed by food, finance, web services and art/culture.

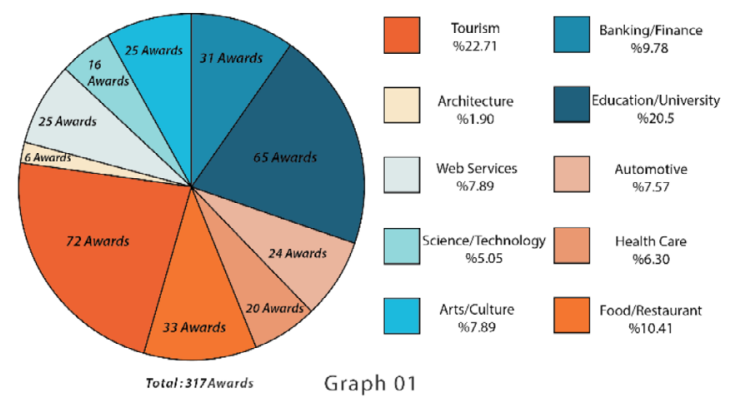

» Figure 4: Sectoral distribution rates of all interactive media awards distributed from 2015 to 2017

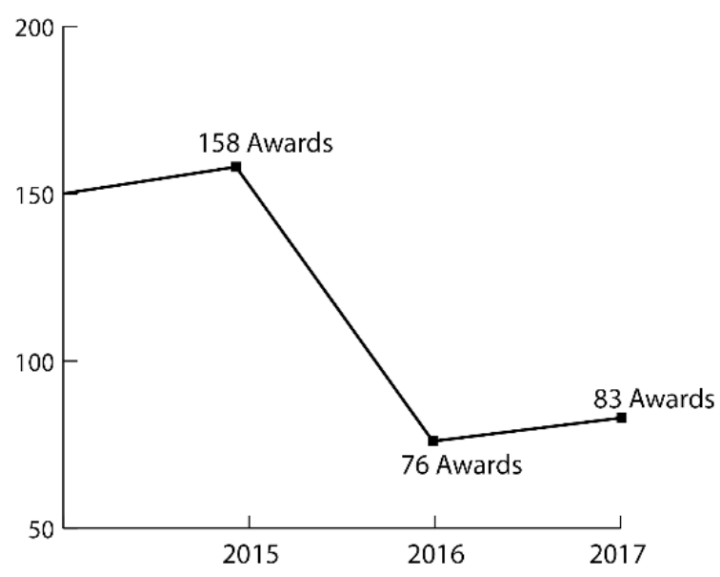

» Figure 5: Change of the number of all interactive media awards distributed from 2015 to 2017 in years
Another piece of statistical information (Figure 5) has attempted to demonstrate the number of awards changing in years to indicate the general tendency of findings.

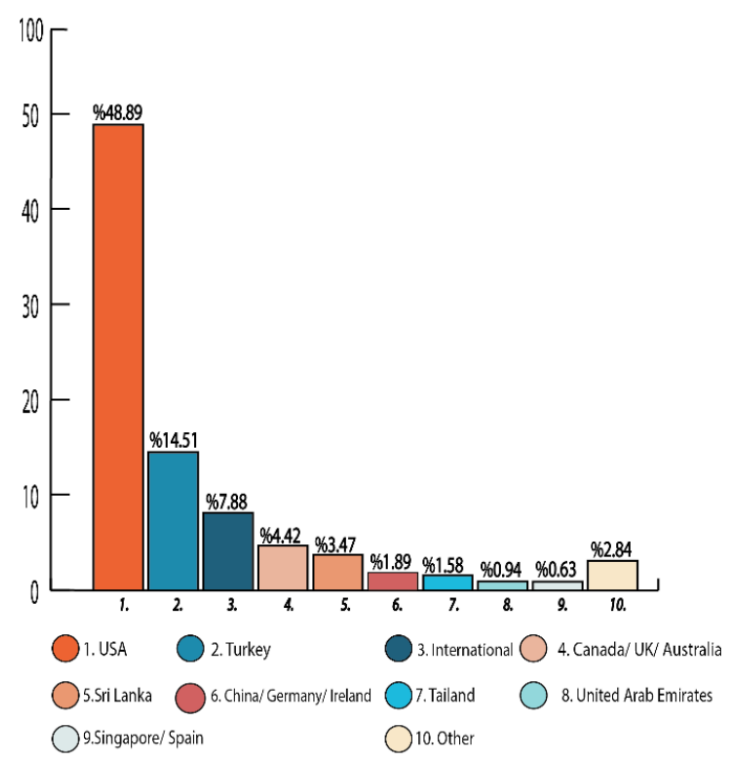

» Figure 6: Country based change rates of all interactive media awards distributed from 2015 to 2017

More than hundred "Interactive Media Awards" have been given away for years every year until 2015 since the dates of inception; while this rate has rapidly reduced in last two years. The number of awards in 2015 is more than twice of the awards given in 2016; however, the number of awards in 2017 is a little lower than the twice of the awards given in 2015. This situation may be associated with the assumption that awards are selective relating to establishment of oriengraph structure.

Ratio differences of countries in line with the awards they won are presented in (Figure 6). As explicitly seen on the graph, almost half of the awards are won by United States of America1. Second rank is occupied by Turkey drawing attention by passing numerous world's giant countries and Turkey is ranked two with significant rate of economic power as America. International companies have taken the third rank with the number of awards almost half of Turkey's and next rank is occupied by England and Canada and Australia composed of English origin communities. Afterwards, a group of European and Asian countries are ranked with fewer percentages and total percentage of these countries may not even reach two third of the percentage of America.

\section{Statistics of Sectors Winning Award in 3 Years Period in 10 Sectors Determined}

Turkey has ranked first by far in "Banking and Finance" sector remained in the fourth place in general average and proved the superiority of interactive media 
design projects in this sector by reaching 3 times the number of awards of USA. Number of awards won by USA has remained approximately at one third of the number of awards won by Turkey.

America produces much more succcessful projects than all other countries in education sector. Award number of all other countries can not reach even half of the award numbers of USA, while, Canada, its neighbour, has reached the closest award number of USA by reaching almost one eighth of the award number. Turkey being limited with only one award reveals the requirement to produce more interactive media project in educational field.

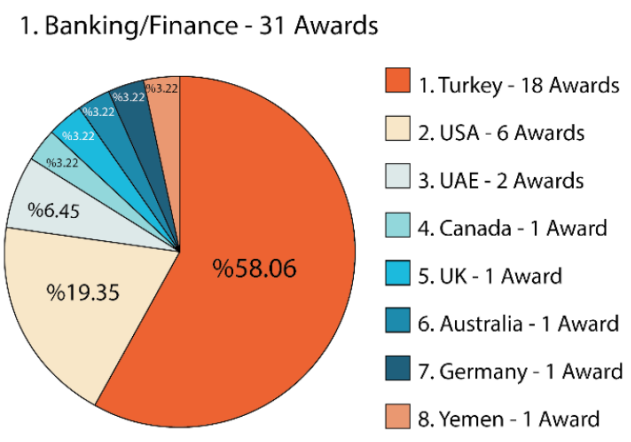

» Figure 7: Distribution rates of countries winning award in 3 years period in Banking/Finance sector

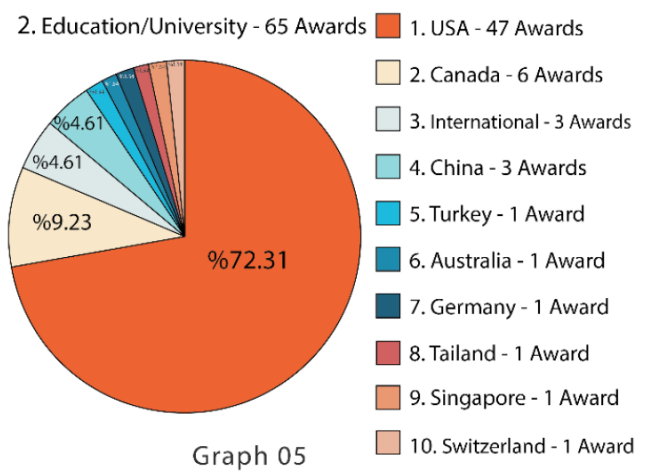

» Figure 8: Distribution rates of countries winning award in 3 years period in Education/University sector

\section{Automotive - 24 Awards}

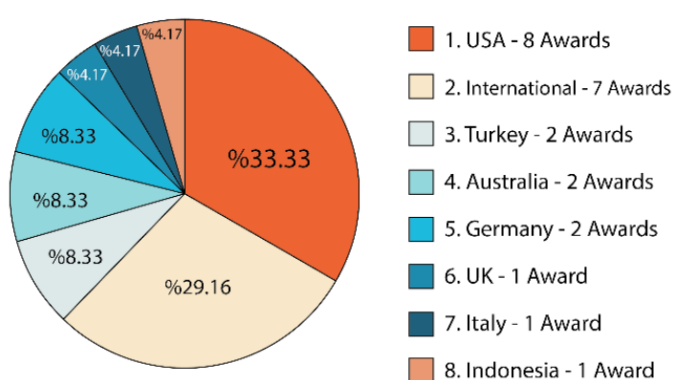

» Figure 9: Distribution rates of countries winning award in 3 years period in automotive sector
First rank of USA in automotive sector may be approached as a result accustomed. However, awarding of two interactive media companies of Turkey in automotive sector named "Project House" (Interactive Media Awards, 2017b) and "Karbonat" (Interactive Media Awards, 2017c) equals to the award number of one of the world leader Germany constitutes a successful result. Most of the awards are won by an international company named "SapientNitro" (Interactive Media Awards, 2017d) after USA.

4. Health Care - 20 Awards

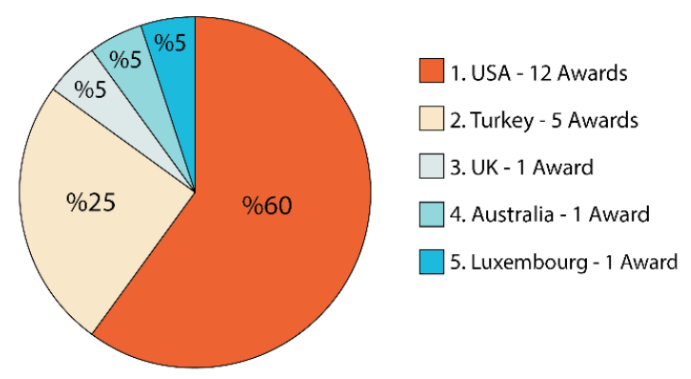

» Figure 10: Distribution rates of countries winning award in 3 years period in Health sector

USA maintains its first rank in health area as in most of other areas. Turkey achieving successful results in the competition engaged with USA has maintained its success by winning quarter of total awards in sector-wide. Countries having higher income rate and life quality compared to Turkey such as Luxemburg, England and Australia have failed to achieve the award number of Turkey and drawn a graph of which results are obvious. Turkey reaching one third of the total number of awards in food and restaurant sector has ranked one. Handing over the interactive media designs of most giant fastfood companies of USA to Turkish interactive media design companies in Turkey has caused it to fall into second rank consequently. Advertisements and web desgins made by Clockwork Agency (Interactive Media Awards, 2017e) to McDonalds, by Karbonat (Interactive Media Awards, 2017c) to Dominos has allowed Turkey to pass USA and International companies.

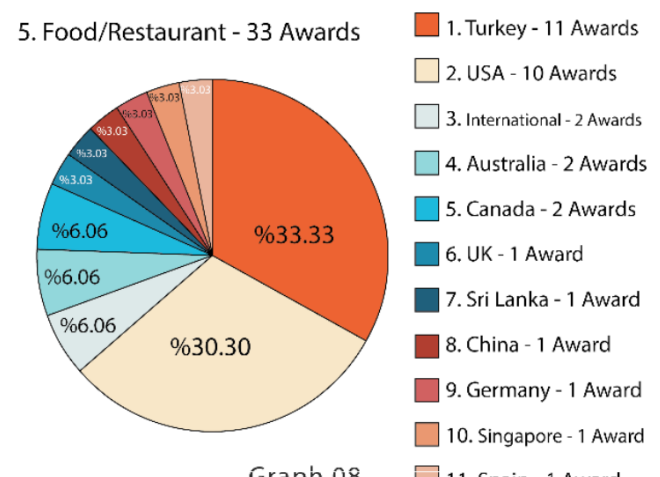

» Figure 11: Distribution rates of countries winning award in 3 years period in Food/Restaurant sector 
Besides, projects designed for domestic companies such as Abant Su (Interactive Media Awards, 2017f), Saklı Orman (Interactive Media Awards, 2017g), Portakal Bahçem (Interactive Media Awards, 2017h), Sütaş (Interactive Media Awards, 2017i) and Kahve Dünyası (Interactive Media Awards, 2017j) are indication of success in this sector.In tourism sector, USA has maintained its superior position by claiming approximately one third of the awards. International companies have followed USA at second rank, Sri Lanka has got close to international companies in tourism sector even it fails to achieve significant successes in other sectors and revealed its potential in the sector. Turkey has failed to achieve a success with high rate in tourism sector with the award rate of approximately one twentieth and placed at rank five. Ten percent of the total number of awards is shared among seven countries winning one award each.

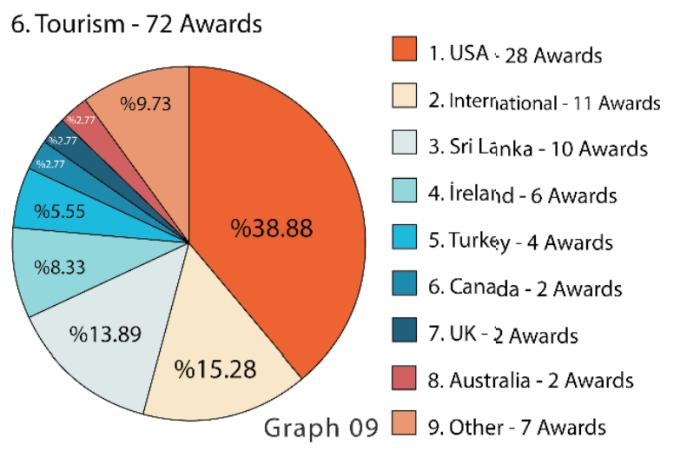

» Figure 12: Distribution rates of countries winning award in 3 years period in Tourism sector

The least promoted sector through interactive media design among these sectors is the Architecture sector and the number of awards have low pro rata with the situation. It is seen that entire awards in the sector are shared among four countries. It is observed that USA has shared the first rank with its neighbor Canada and that these two friendly countries have reached twice the number of awards won by Turkey and England.

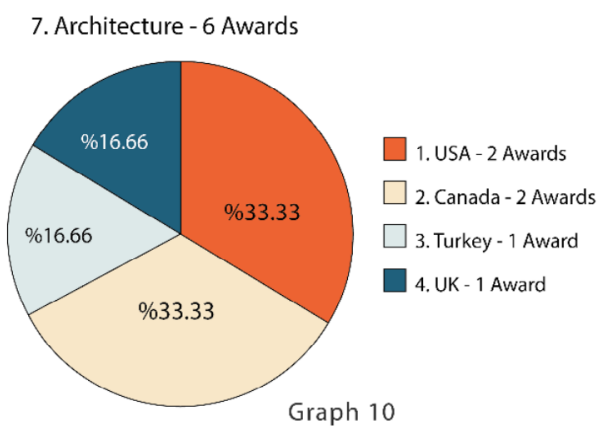

» Figure 13: Distribution rates of countries winning award in 3 years period in Architecture sector

Superior position of USA is once more seen in the web services sector. Second rank is shared among Turkey and Canada with two awards each, all of the remaining companies has settled with only one award.
All other awards in web services sector cannot reach two third of awards won by USA and limited with the awards almost half of the awards won by USA. Main American companies dominating the sector with 25 creative web sites are interactive media companies such as "Smack Happy" (Interactive Media Awards, 2017k), "8th Sphere" (Interactive Media Awards, 2017l), "Cake\&Arrow" (Interactive Media Awards, 2017m) and "Ascedia" (Interactive Media Awards, 2017n).

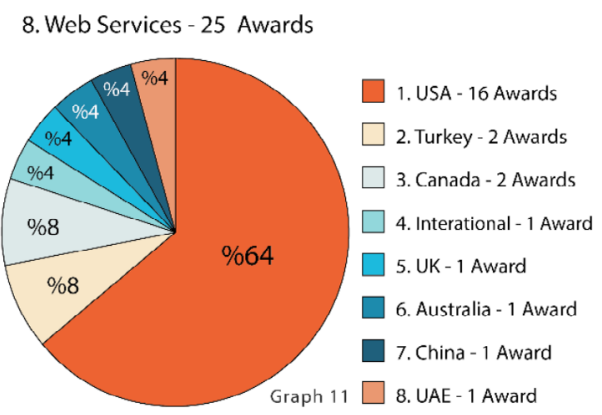

» Figure 14: Distribution rates of countries winning award in 3 years period in Web Services sector

As expected, it is observed that USA has won ten times of the awards compared to its following competitor and more than two third of the total awards in Science and Technology. It may be assumed that scientific and technological works performed around the World are made in USA in line with the award-winning rate. It is worth attention that Turkey is included to countries winning the award in the sector in which very few countries have won an award. It also attracts attention that Scotland and Thailand are included into countries whose total number of awards may not event match half of the awards won by USA.

\section{Science/Technology - 16 Awards}

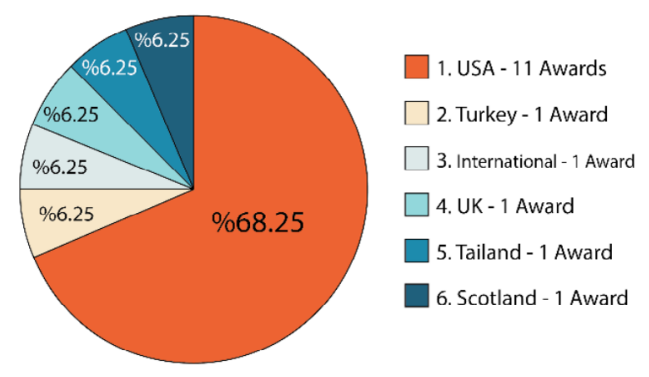

» Figure 15: Distribution rates of countries winning award in 3 years period in Science/Technology sector

It is observed that USA has reached higher rates compared to its competitors also in art and culture sector. While England has won one third of the awards of USA and total awards of Australia and Thailand equals to the number of England. 
10. Arts/Culture - 25 Awards

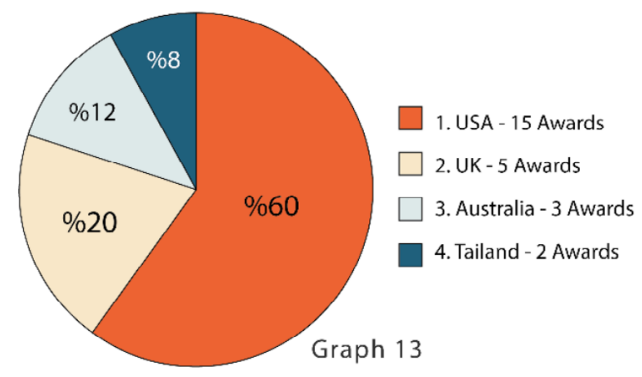

» Figure 16: Distribution rates of countries winning award in 3 years period in Art/Culture sector

\section{Statistics of Countries in 3 years Period in 10 Sectors Determined}

This section will inspect which country has won how many awards in which sector along with the graphics sorted according to award winning rate of the countries and it will be attempted to observe the tendencies of countries in aspect of sectors and that which fields are focused by the interactive media sector. Although we have observed in the graphics that how 317 awards are distributed among the countries, determining the sector distribution of countries among themselves will be more explanatory with this method and clarify the sector tendencies on country basis.

USA strongly maintains its position at first rank with 155 awards. Country holding most awards in the number of 47 in education sector has won almost one third of the awards from this sector. It has achieved great success with 28 awards in tourism sector after the education sector.

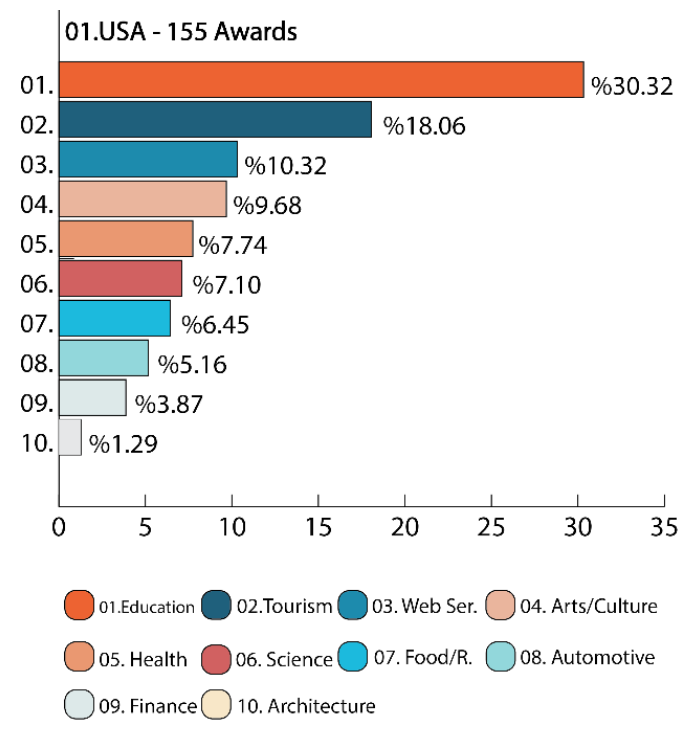

» Figure 17: Distribution rates of sectors awarded in 3 years period to United States of America
Country holding 16 awards causing global domination in web services draws a country profile that does not only develop in technical sectors but also maintains its success in art and culture sector by winning 15 awards in the art and culture sector. The number of awards dropping from 12 to 6 in other sectors has finally reduced to 2 awards in architecture however this success allowed the country to hold first rank even in architecture sector granting awards quite less.

If we overview the position of Turkey, success in the finance sector can be seen clearly. A significant success covering 18 awards among 46 and comprising forty percent is obtained from this sector. Country winning also 11 awards in food sector has obtained 5 awards in health, 4 awards in tourism and 2 awards in automotive, architecture and web sectors each and 1 award in education and science sectors each. Since these awards allowing the country to hold second rank in global scale are not obtained by many European country, it is necessary to mention about noticeable success.

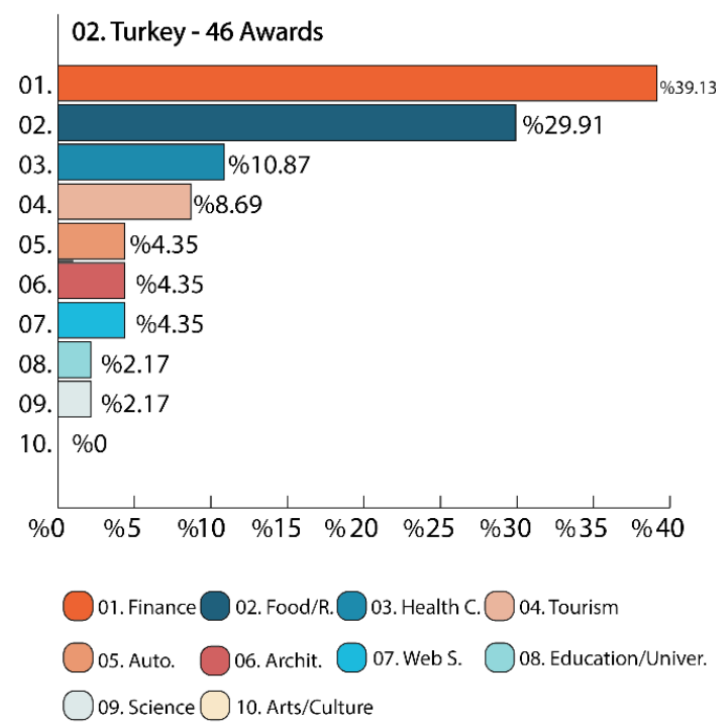

» Figure 18: Distribution rates of sectors awarded in 3 years period to Turkey

In this era, when the international companies reach at their peak point in global economy, it is possible for them to pass Turkey even USA and reach the first rank. However, in relation to the cooperation of countries, it may be mentioned about the success of strong and creative economies among themselves. Almost half of the awards won by international companies are related to tourism sector. As an indication of this, it may be assumed tourism sector contains more global behavior. International companies achieving high level of success with 11 awards in tourism sector have won 7 awards in automotive sector and 3 awards in education sector with the interactive media projects. Companies winning 2 awards in food and restaurant sectors have remained 
in 1 award in web services, science and technology fields and could not win any awards in other sectors.

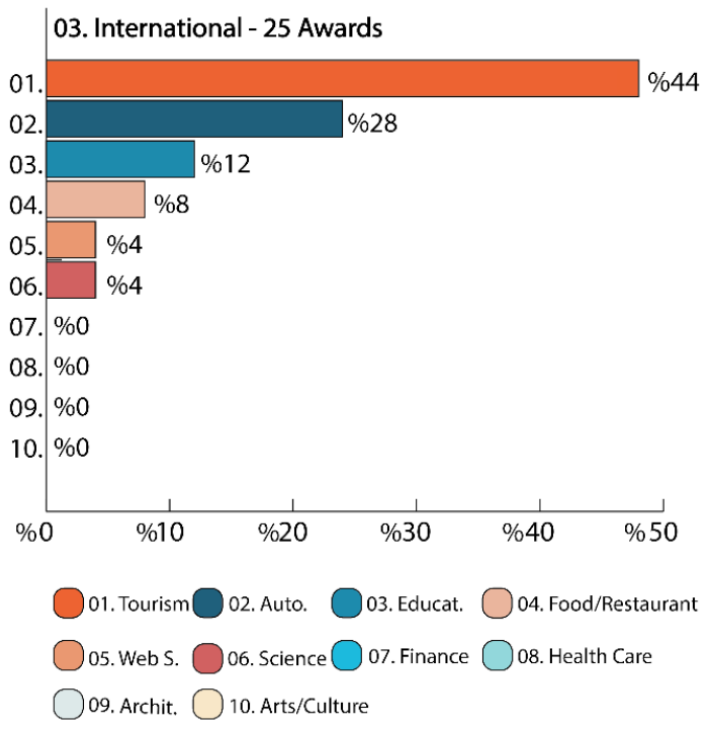

» Figure 19: Distribution rates of sectors awarded in 3 years period to International Companies

Canada; the large of the North, follows USA. It may be assumed that both countries in approximate geography and similar structure having such difference is caused by the changes in economic structure and creativity level. Canada has won 6 awards almost half of its total awards from education sector. Success of the country relating to marketing of education is perceived from the number of its awards. Country winning 2 awards in food, web and tourism sectors each has won only 1 award in architecture and finance.

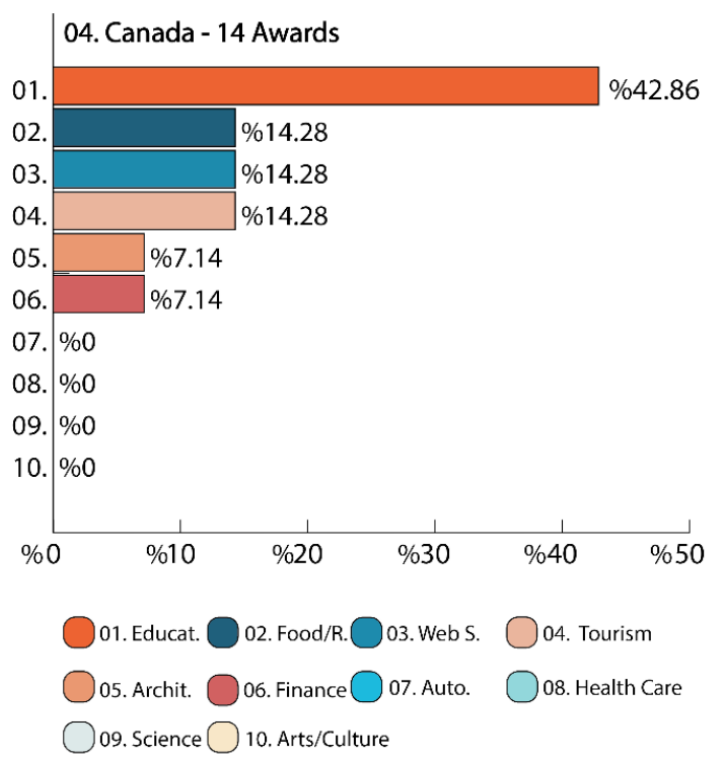

» Figure 20: Distribution rates of sectors awarded in 3 years period to Canada

\section{UK - 14 Awards}

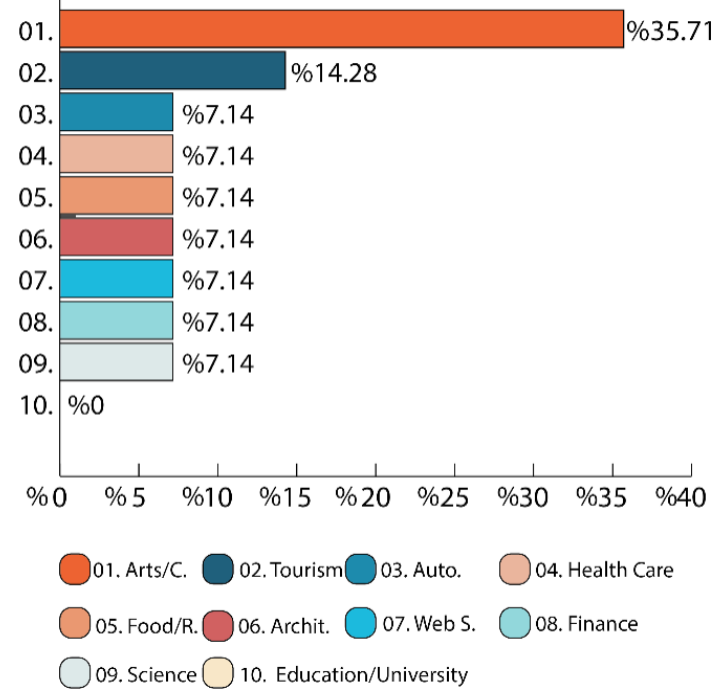

» Figure 21: Distribution rates of sectors awarded in 3 years period to England

England is deemed worthy of the same number of awards with Canada as older colony, while it has passed Australia with one award. Country considered as one of the strong forces in the world falling behind America and Turkey may be considered as the success of Turkey or the failure of England. England has won one third of its awards in art and culture sectors. Global development is obtained not only by finance and food but also in art and culture if we consider that Turkey has no award in this sector. Country winning 5 awards in this sector has won 2 awards in tourism, none in education sector and only 1 award in all other sectors.

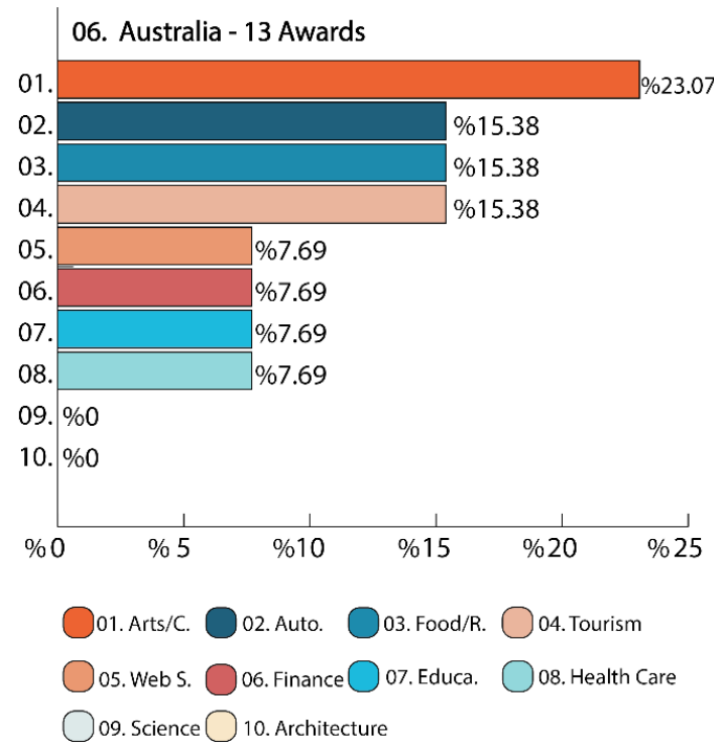

» Figure 22: Distribution rates of sectors awarded in 3 years period to Australia 
Australia; another former English colony has drawn similar success graphic. Country has obtained more than one fifth of its awards from art and culture sector. It may be assumed that another country has obtained its civilization level with the value attached to art. Interactive media designs as focus point of the research is formed according to social tendencies of countries. Country winning 3 awards in art and culture, 2 awards in automotive, food and tourism each has won 1 award in finance and education sectors each, while it has no success in science and architecture with interactive media design.

We may mention that ranking of Sri Lanka above countries with higher economical force such as China, Germany and Ireland is caused by interactive media design agency named "eMArketingEye" (Interactive Media Awards, 2017o). Because nine tenth of the awards received are won by this company and rightful success of the company is revealed. Country winning another award in food sector has succeeded to rank higher compared to its economic potential and tendency.

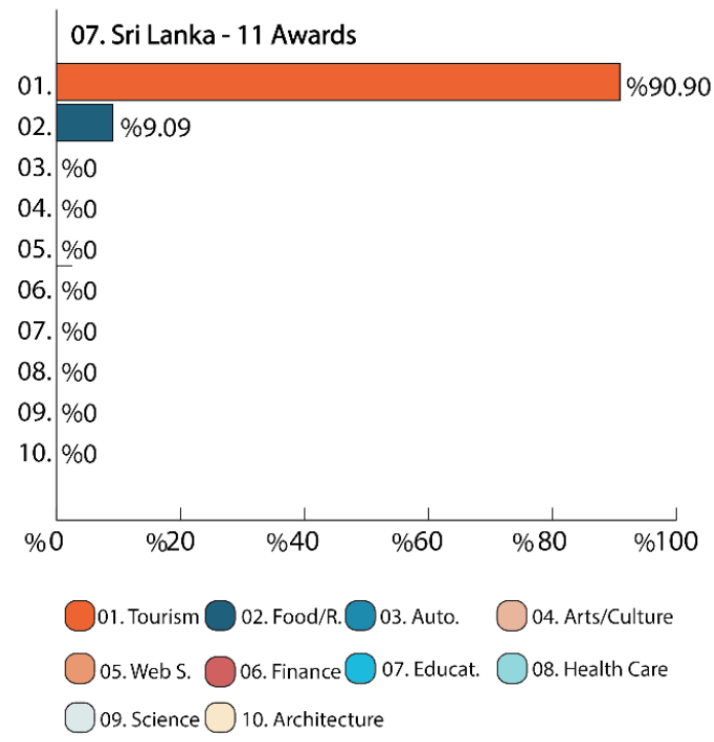

» Figure 23: Distribution rates of sectors awarded in 3 years period to Sri Lanka

China confining itself with only 6 awards despite having the most crowded population in the World may suggest that it fails to compensate the requirements of interactive media design sector as required. Country winning three awards in education sector among total of six awards won has obtained three awards in food, tourism and web services sectors in conjunction. It may be assumed that the economic potential of country failed to obtain award in other sectors is not fully compensated on the creativity sector.

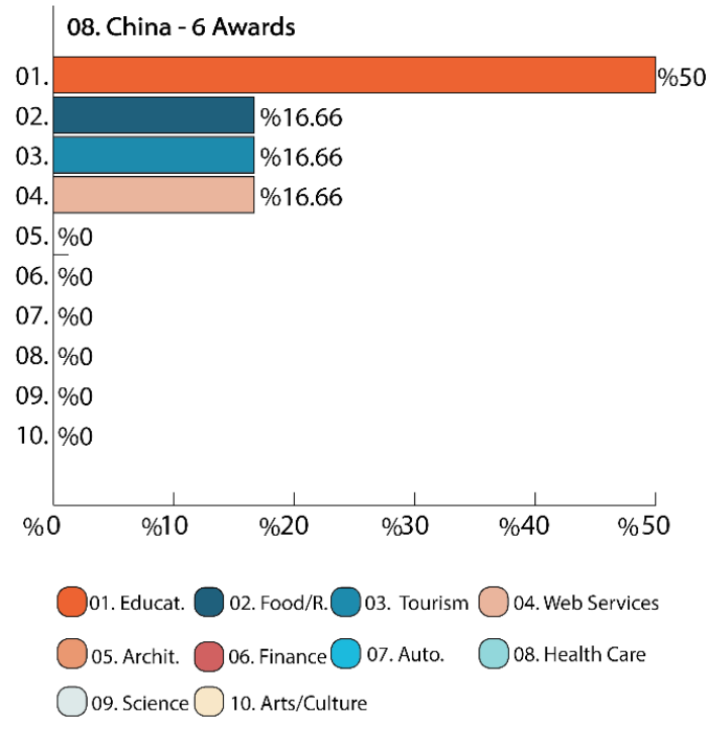

» Figure 24: Distribution rates of sectors awarded in 3 years period to China

Germany has entered the list on even lower ranks on the contrary of many other European countries. The country having high level of success in automotive and medicine industry on global market fails to indicate the same performance in creativity like China. The country winning one third of the six awards won in automotive sector has equally distributed other awards into food, tourism, finance and architecture sectors.

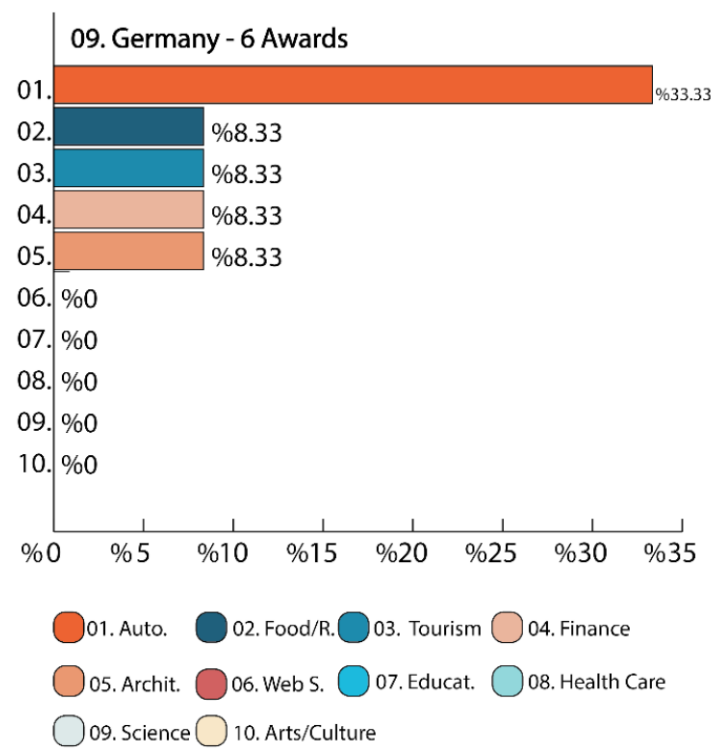

» Figure 25: Distribution rates of sectors awarded in 3 years period to Germany

The success of the country indicating existence only in half of the ten sectors elected is caused by being one of the rare countries, whose existence is determined on interactive media field in its continent as mentioned above. Ireland has gained to right to enter the list from the last ranks with a behavior that may be considered as 
coincidental by benefitting from the tourism sector in interactive media field. Since all of the 6 awards held by country are won in tourism sector, it may be assumed that the country attaches necessary importance to its nature and history. This country sharing the culture of England at this level failing to achieve success in other sectors may be caused by economic or political reasons.

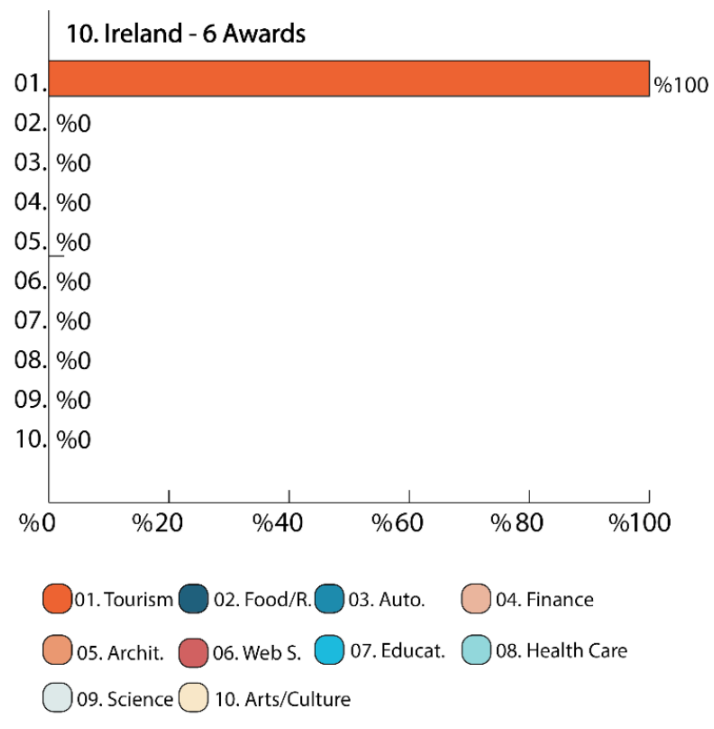

» Figure 26: Distribution rates of sectors awarded in 3 years period to Ireland

While Thailand is not included in the list of countries with high economy level, it has achieved success by finding a place in interactive media field even as one of the last countries. It will be considered as accepted graph success for the country to include into list with five awards and three categories during which even China has won 6 awards.

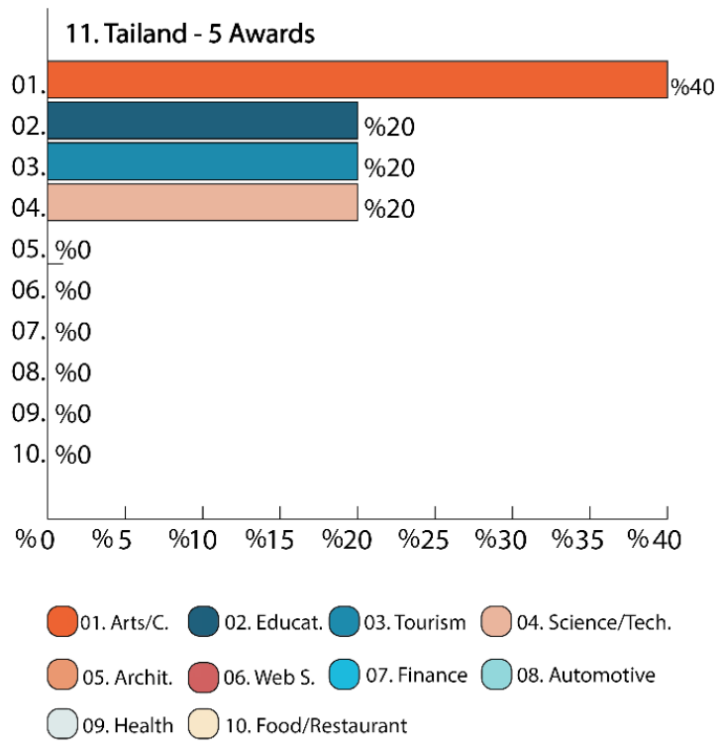

» Figure 27: Distribution rates of sectors awarded in 3 years period to Thailand
The country winning 2 of the awards won in art and culture sectors has achieved success of being one of the four countries winning award in art and culture sectors. The country obtaining its three other awards in education, tourism and science sectors failed to win awards in other 6 categories.

Two third of the success of UAE is related to banking and finance sectors. 2 of the 3 awards won are obtained from this sector. Another award of United Arab Emirates as the sole country to achieve success of entering the list from Middle East is in web services sector. It will be assumed that the success of the country failing to obtain award from other eight categories is due to being the only country having its name written on the list from Middle East.

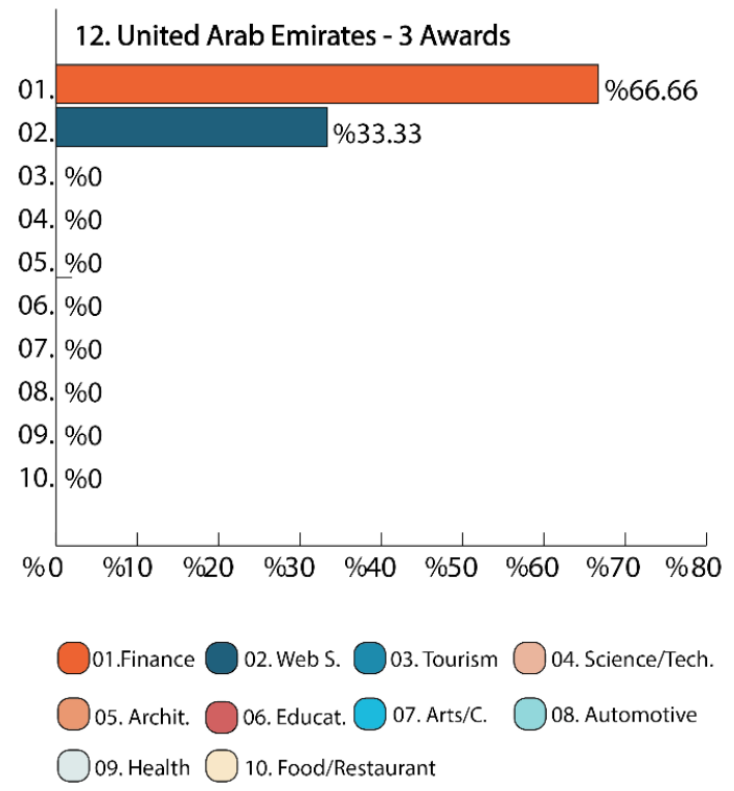

» Figure 28: Distribution rates of sectors awarded in 3 years period to United Arab Emirates

\section{Statistics of Years Awarded on Sector Basis in 3 Years Period in 10 sectors determined}

It is seen that the number of awards given in 2015 is far over 100. It is also observed that the awards were distributed more and difficulty level of winning an award was not so high.

In 2015, interactive media agencies are rewarded mostly in tourism sector with 39 awards and almost quarter of the awards in entire year are distributed in this sector. While education and university closely sector follows the tourism with 36 awards, third rank is occupied by banking and finance with the number of awards less than half of the tourism sector. 
2015 - 158 Award
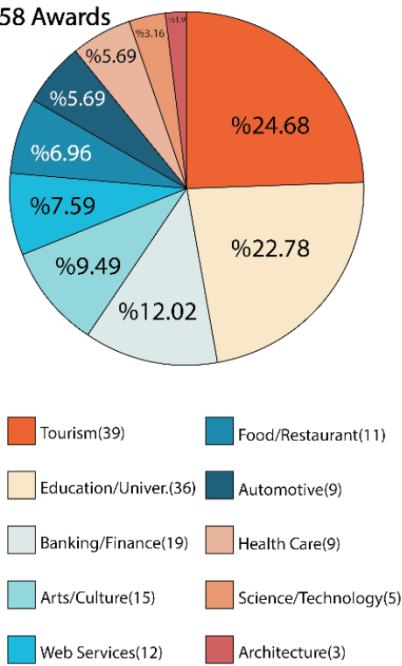

» Figure 29: Statistics of awards received in 2015 on sector basis in 10 sectors determined

Art and culture sector is ranked five with 15 awards, while web services and other categories have followed art and culture.

In 2016, the number of awards has been reduced by half and awards are distributed in equal scales on sector basis. While more than quarter of the entire year contains interactive media designs in education and university sectors, tourism has followed these sectors with 15 awards. While 8 awards are distributed in banking and finance categories, 7 awards are distributed in food and web design fields. While 12 projects deemed worthy of 6 awards in science and art categories are generated, total of 8 projects have won awards in automotive and health sectors and only 2 designs were produced having quality for award in architecture.

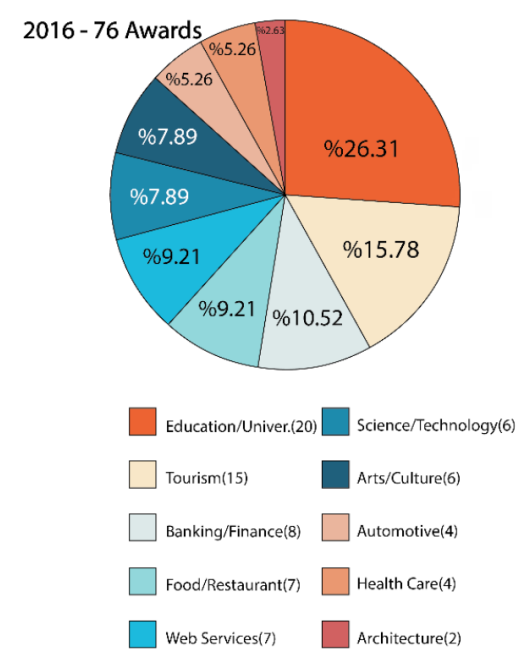

» Figure 30: Statistics of awards received in 2016 on sector basis in 10 sectors determined

In 2017, number of awards has increased slightly compared to previous year and 83 awards are distributed.

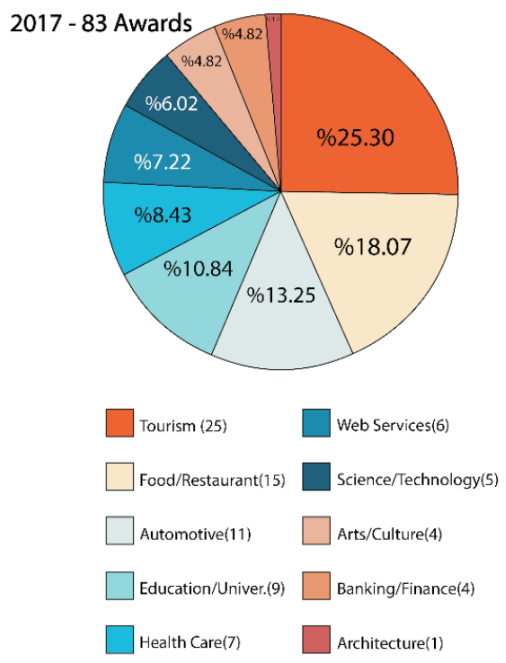

» Figure 31: Statistics of awards received in 2017 on sector basis in 10 sectors determined

One fourth of the awards is given in tourism sector as in 2015 and food and restaurant sector has followed this sector with 15 awards. By considering the general tendency of the awards given, it may be assumed that more awards are distributed and more designs are made on sectors related with consumption. 11 awards in automotive sector, 9 awards in education sector, 7 awards in health sector were distributed in 2017 and interactive media projects were produced to obtain 20 awards in total in other sectors.

\section{Statistics of Awards Received in 3 Years Period on Country Basis in 10 sectors Determined}

Although the number of awards is high in 2015, there is no country having more than 10 awards other than the number of awards received by USA, Turkey and international companies. More than half of the awards shared this year have gone to United States of America, one tenth of them to Turkey, almost nine percent of the awards are given to international companies. Only England, Germany, Ireland and Spain are deemed worthy for award in Europe continent and total awards of these four countries could not even reach the award number of Turkey. While England has won 9 awards, Sri Lanka and Canada has confined themselves with 7 awards. Award number of Canada is less than twelve times of the award number of USA.

Exactly half of the awards in 2016 are given to USA. Only 2 of the 11 countries have won more than 10 awards and these countries are Turkey and United States of America. Only 2 countries are included to list from Europe continent and total award number of all other countries could not achieve number equals to award number of USA. In this year when Canada is placed third with 6 awards, England, Australia and China have only achieved fifth rank with 3 awards. In 
the list where United Arab Emirates has ranked last with 1 award, Germany shared the same status.

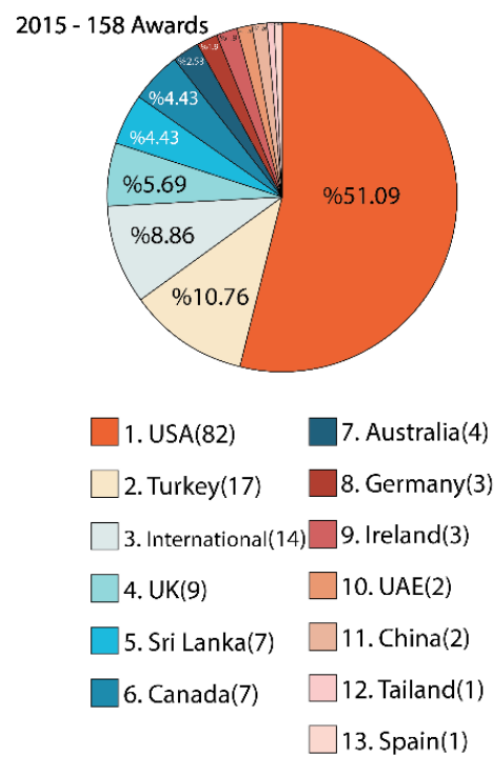

» Figure 32: Statistics of awards received in 2015 on country basis in 10 sectors determined

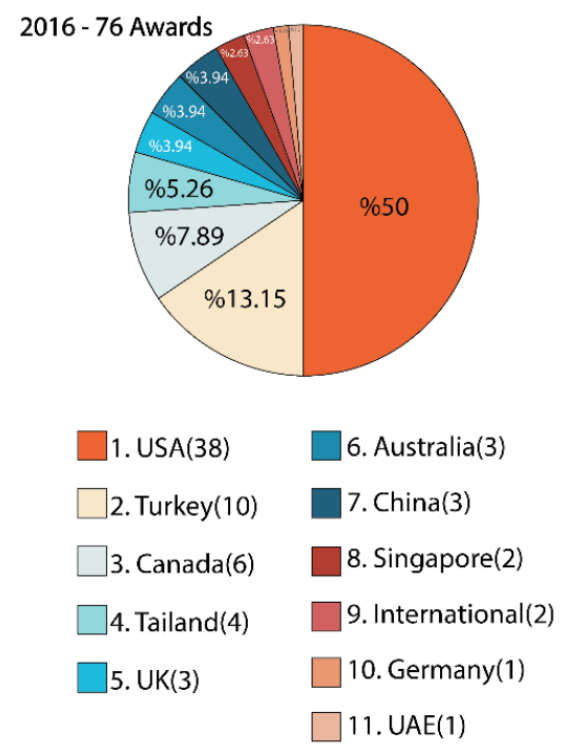

» Figure 33: Statistics of awards received in 2016 on country basis in 10 sectors determined

In 2017, share of United States of America has been reduced down from fifty percent to lower level for the first time and share of other countries is increased slightly. After USA obtaining only 35 of 83 awards, second rank is taken by Turkey without disrupting its stability and it did not lose its position to any of its competitors. Turkey having more than half of the awards won by USA has won almost one fourth of all awards. While interactive media projects of international companies winning awards after Turkey is limited with 9 awards, Australia and Sri Lanka ranked fourth and fifth have won total of 10 awards. Total awards of coun- tries ranked third, fourth and fifth could only reach to number equals to the award number of Turkey.

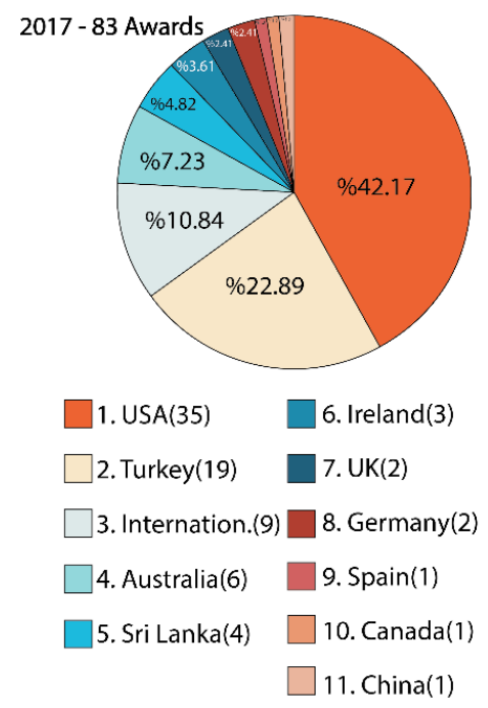

» Figure 34: Statistics of awards received in 2017 on country basis in 10 sectors determined

\section{The Place of Turkey in General Average in 10 Sectors Determined}

Turkey has achieved second rank after USA on global market by obtaining 46 of 317 awards and drawn a very successful profile in all sectors other than art/culture category. Turkey obtaining almost fifteen percent of all awards has proved its potential to entire world by obtaining the most awards in worldwide in finance and banking sector. United States of America has achieved the success materialized with its giant economy through companies producing projects with their young and creative personnel and has demonstrated its power on global scale by ignoring economic development rates of many European and Asian countries. Requirement of closing the gap in art and culture category has become significant due to failure of obtaining no award in this sector for three years period.

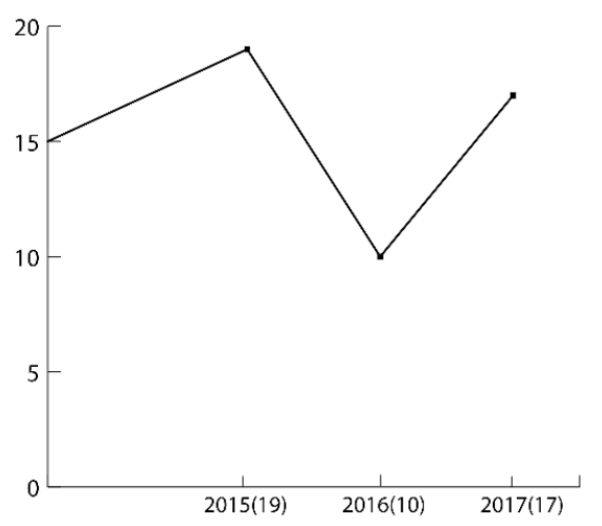

» Figure 35: Changing rates in the number of awards of Turkey within years in 10 sectors determined 


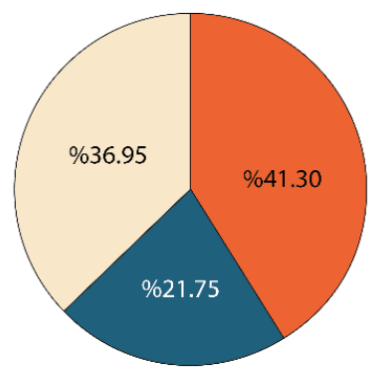

2015(19)

2016(10) $\square 2017(17)$
Graph 33

» Figure 36: Changing rates in the number of awards of Turkey within years in 10 sectors determined

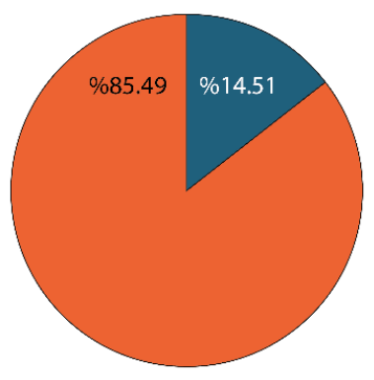

$\square$ Turkey $\square$ Others

Graph 34

» Figure 37: Place of Turkey in general average in 10 sectors determined

It has maintained its great success in banking and finance sector with interactive media projects prepared for food sector and demonstrated its victory on global scale with 46 awards in total and minimum 1 award in each category excluding art and culture sector.

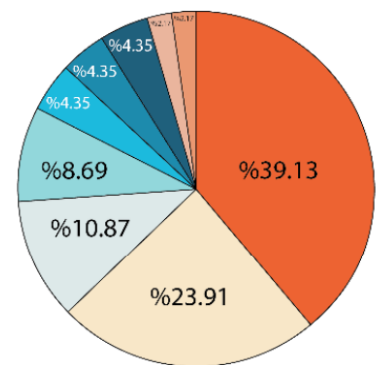

Banking/Finance(18)

Food/Restaurant(11) Web Services(2)

$\square$ Healt Care(5) $\quad \square$ Education/University(1)

Tourism (4) $\square$ Science/Technology(1)

Automotive(2) $\quad \square$ Arts/Culture(0)

Graph 35

» Figure 38: Distribution rates of awards won by Turkey in 3 years period on sector basis
It has gained rightful success in health, tourism, automotive, architecture and web services sectors and clinched its success by leaving the world giants behind and also the European and Asian countries whose names not even referred in most times.

\section{Conclusion}

It may be considered that we are at the beginning of great technological revolution on a global scale. Multi systems, existence of hyper reality in cyber space and limitlessness of interaction in every direction may progress to clinch this revolution. The world does not seem to be controlled from single center when we consider the interactivity and the reflection of such interactivity on media. It may also be considered that United States of America has dominated this area by controlling half of the interactive media sector suggested throughout this research; however, there are countries having very strong effects on the other half. As indicated by the research, it will be assumed with strong argument that Turkey is one of these countries. It is followed by international companies and this sequence is also followed by countries such as England, Canada and Australia. Since we may assume that the foundation of interactive media sector is comprised of technology and design, cooperation of science and art may be considered as sufficient to explain the ability potential on this sector. Although it is observed that not many projects are produced in sectors including science and art, it may be considered as an example of success of Turkey for being in high ranks in the first five countries demonstrating success in worldwide for the performance in science and art. As seen on Graph 35 and 36, although award winning rate has significantly been reduced in 2016 compared to 2015 , this rate is raised for Turkey in 2017. These rates have been reduced by half in 2015 on global scale and continued to remain within these limits, however Turkey will be considered as drawn a more successful graphic compared to other countries in global aspect by approximating its award rate in 2017 to 2015 . When we viewed in global scale such as finance, food, health and tourism, it will be considered as another gain for Turkey to win awards densely in more awarding sectors and for which more projects are produced. Turkey succeeded in following super force USA in all the previous figures, on which names of Latin America countries, most of European Union countries, Africa countries, Russia, Japan and many more important countries are not even referred, is successful because of leaving first World countries behind on the subjects of interaction and creativity. 


\section{References}

Bulduk, B. (2015) Etkileşimli Medya ve Öğretim OrtamIarında Tasarım Geliştirme Süreci. Sanat ve Tasarım Dergisi. 16, 47-63. Available from: doi: 10.18603/ std.92341

Dix, A., Finlay, J., Abowd, G. D. \& Beale, R. (2004) Human-Computer Interaction. Haddington, Scotprint. Available from: https://www.pearson.com/us/higher-education/program/Dix-Human-Computer-Interaction-3rd-Edition/PGM268779.html [Accessed: 10th December 2017].

England, E. \& Finney, A. (2002) Interactive media- What's that? Who is Involved? In: ATSF White Paper, Interactive Media U.K., United Kingdom. Available from: http://www.atsf.co.uk/atsf/interactive_media.pdf [Accessed: 25th December 2019]

Interactive Media Awards. (2017a) Honoring outstanding achievement in website design and development. Available from: https://interactivemediaawards.com/ [Accessed: 10th December 2017].

Interactive Media Awards. (2017b) Project House Award Gallery. Available from: https://interactivemediaawards.com/winners/gallery.asp?id=130814 [Accessed: 10th December 2017].

Interactive Media Awards. (2017c) Karbonat Award Gallery. Available from: https://interactivemediaawards. com/winners/gallery.asp?id=58254 [Accessed: 10 th December 2017].

Interactive Media Awards. (2017d) SapientNitro Award Gallery. Available from: https://interactivemediaawards.com/winners/gallery. asp?id=54321 [Accessed: 10th December 2017].

Interactive Media Awards. (2017e) Clockwork Agency Award Gallery. Available from: https://interactivemediaawards. com/winners/gallery. asp? id=47997 [Accessed: 10th December 2017].

Interactive Media Awards. (2017f) Winners - Abant Su. Available from: http://interactivemediaawards.com/ winners/certificate. asp? param $=480060 \&$ cat $=1$ [Accessed: 10th December 2017].

Interactive Media Awards. (2017g) Winners - Saklı Orman. Available from: http://interactivemediaawards. $\mathrm{com} /$ winners/certificate. asp ? param $=765016 \&$ cat $=1$ [Accessed: 10th December 2017].
Interactive Media Awards. (2017h) Winners - Portakalbahcem. Available from: http://interactivemediaawards.com/winners/certificate.asp? param $=764960 \&$ cat $=1$ [Accessed: 10 th December 2017].

Interactive Media Awards. (2017i) Winners - Sütaş Dairy Products. Available from: http://interactivemediaawards.com/winners/certificate.asp ?param $=763063 \&$ cat $=1$ [Accessed: 10 th December 2017].

Interactive Media Awards. (2017j) Winners - Kahve Dünyası UK. Available from: http://interactivemediaawards.com/winners/certificate.asp ? param $=762706 \&$ cat $=2$ [Accessed: 10 th December 2017].

Interactive Media Awards. (2017k) Winners - Smack Happy Design. Available from: https://www.interactivemediaawards.com/winners/certificate. asp? param $=764414 \&$ cat $=1$ [Accessed: 10 th December 2017].

Interactive Media Awards. (2017l) Winners - 8th Sphere. Available from: https://www.interactivemediaawards. $\mathrm{com} /$ winners/certificate. asp ? param $=571186 \&$ cat $=1$ [Accessed: 10th December 2017].

Interactive Media Awards. (2017m) Cake \& Arrow Award Gallery. Available from: https://interactivemediaawards.com/winners/gallery.asp?id=31753 [Accessed: 10th December 2017]. Interactive Media Awards. (2017n) Ascedia Award Gallery. Available from: https://interactivemediaawards. com/winners/gallery.asp?id=106642 [Accessed: 10th December 2017].

Interactive Media Awards. (2017o) eMarketingEye Award Gallery. Available from: https://interactivemediaawards.com/winners/gallery.asp?id=50085 [Accessed: 10th December 2017].

Mora-Fernández, J. (2012) The Analysis of Interactive Media and Digital Culture- Hypermedia Literacy in Peru and Bolivia. Comunicar. 20 (39), 139-149. Available from: doi: 10.3916/c39-2012-03-04 [Accessed: 11th December 2017].

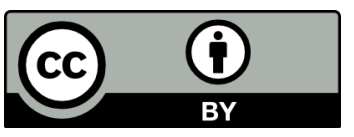

(C) 2019 Authors. Published by the University of Novi Sad, Faculty of Technical Sciences, Department of Graphic Engineering and Design. This article is an open access article distributed under the terms and conditions of the Creative Commons Attribution license 3.0 Serbia (http://creativecommons.org/licenses/by/3.0/rs/). 